NBER WORKING PAPER SERIES

\title{
PRECAUTIONARY SAVINGS AND THE IMPORTANCE OF BUSINESS OWNERS
}

\author{
Erik Hurst \\ Annamaria Lusardi \\ Arthur Kennickell \\ Francisco Torralba \\ Working Paper 11731 \\ http://www.nber.org/papers/w11731 \\ NATIONAL BUREAU OF ECONOMIC RESEARCH \\ 1050 Massachusetts Avenue \\ Cambridge, MA 02138 \\ November 2005
}

We would like to thank Rob Alessie, Chris Carroll, John Cochrane, Luigi Guiso, David Romer, Paola Sapienza, Karl Scholz, Richard Thaler, James Ziliak and participants to the NBER Monetary Economics Summer Institute, the macroeconomics and microeconomic workshop at the Graduate School of Business of the University of Chicago, the macroeconomic seminar at the Federal Reserve Bank of Chicago, the public economics seminar at the University of Wisconsin, the workshop on "Household Choice of Consumption, Housing and Portfolios" at the University of Copenhagen, and the macroeconomic seminar at the Dutch Central Bank for suggestions and comments. Any errors are our responsibility. This paper was written while Lusardi was visiting the Graduate School of Business of the University of Chicago and its hospitality is gratefully acknowledged. Hurst acknowledges financial support from the Charles E. Merrill Faculty Research Fund at the Graduate School of Business of the University of Chicago. Torralba acknowledges financial support from the Bank of Spain. The opinions expressed in this paper do not necessarily reflect the views of the Board of Governors of the Federal Reserve System or the Bank of Spain. The views expressed herein are those of the author(s) and do not necessarily reflect the views of the National Bureau of Economic Research.

(C2005 by Erik Hurst, Annamaria Lusardi, Arthur Kennickell, and Francisco Torralba. All rights reserved. Short sections of text, not to exceed two paragraphs, may be quoted without explicit permission provided that full credit, including $\odot$ notice, is given to the source. 
Precautionary Savings and the Importance of Business Owners

Erik Hurst, Annamaria Lusardi, Arthur Kennickell, and Francisco Torralba

NBER Working Paper No. 11731

November 2005

JEL No. E2

\section{ABSTRACT}

In this paper, we show the pivotal role business owners play in estimating the importance of the precautionary saving motive. Since business owners hold larger amounts of wealth than other households for non-precautionary reasons and also face highly volatile income, they induce a correlation between wealth and income risk regardless of whether or not a precautionary saving motive exists. Using data from the Panel Study of Income Dynamics in the 1980s and the 1990s, we show that among both business owners and non-business owners, the size of precautionary savings with respect to labor income risk is modest and accounts for less than ten percent of total household wealth. However, pooling together the two groups leads to an artificially high estimate of the importance of precautionary savings. New data from the Survey of Consumer Finances further confirms that precautionary savings account for less than ten percent of total wealth for both business owners and non-business owners. Thus, while a precautionary saving motive exists and affects all households, it does not give rise to high amounts of wealth in the economy, particularly among those households who face the most volatile stream of income.

Erik Hurst

University of Chicago

Graduate School of Business

Chicago, IL 60614

and NBER

erik.hurst@gsb.uchicago.edu

Arthur Kennickell

Board of Governors of the Federal Reserve System Mail Stop 180

Washington, DC 20551

arthur.kennickell@frb.gov
Annamaria Lusardi

Department of Economics

Dartmouth College

Hanover, NH 03755

and NBER

annamaria.lusardi@dartmouth.edu

Francisco Torralba

Department of Economics

University of Chicago

Chicago, IL 60614

ftorralb@uchicago.edu 


\section{Introduction}

Precautionary saving is considered one of the most important motives to save, particularly among the young population. While a variety of empirical estimates exist, several studies show that precautionary savings may contribute to as much as fifty percent of aggregate wealth for individuals under the age of fifty. ${ }^{1}$ The general approach taken in these empirical studies is to relate measures of labor income risk faced by households to the amount of wealth households accumulate. As a result of these large empirical estimates, most models in macroeconomics now incorporate a precautionary saving motive. Moreover, the importance of precautionary savings has implications for public policy; the effects of welfare and taxation policies very much rely on the strength of this motive.

One of the critical problems of the existing empirical work on precautionary savings is that researchers pool together two distinct sub-groups within the population: business owners and all other households. ${ }^{2}$ Such mixing has the potential to confound the analysis of precautionary savings. As we show, business owners face, on average, higher expected income risk and accumulate larger amounts of wealth than other households for reasons unrelated to precautionary savings. For example, pension coverage rates are much lower for business owners than for non-business owners. Those who own their business, as a result, must accumulate more private wealth to sustain consumption during retirement. Business owners also display a stronger bequest motive than other households. The fact that business owners hold higher-than-average wealth

\footnotetext{
${ }^{1}$ For a review of early work on precautionary savings, see Browning and Lusardi (1996). For more recent results, see Carroll and Samwick $(1997,1998)$ and Kazarosian (1997).

${ }^{2}$ As in Quadrini (1999) and Hurst and Lusardi (2004), we define business owners as households who report owning their own business and we use the terms entrepreneurs and business owners interchangeably. In our robustness specifications, we also define business owners as households who report being self-employed.
} 
while facing larger measured income risk than other households will lead to a correlation between wealth and labor income risk regardless of whether or not a precautionary motive is important. In this paper, we explicitly show that the large positive estimates of precautionary savings documented in the literature are, in fact, an artifact of pooling together business owners and non-business owners.

To test this hypothesis, we separately analyze precautionary saving motives within a group of non-business owners and within a group of business owners using data from the Panel Study of Income Dynamics (PSID). Within each group, we find that precautionary savings explain only up to ten percent of total household wealth. Yet, when we pool these samples together, we find results consistent with other empirical estimates on the importance of precautionary savings. Specifically, in the pooled sample, we find that as much as fifty percent of total wealth is explained by precautionary savings.

The novelty of our work is not only to show the pivotal role business owners play in estimating the importance of precautionary savings, but also to show that the high amount of wealth held by business owners is not the result of their precautionary motive to save against income risk. In fact, the relationship between wealth and risk may simply reflect the risk-return tradeoff of the projects undertaken by business owners rather than their desire to shield themselves against shocks to income.

In the final part of the paper, we use a more direct approach to estimating the importance of precautionary savings. Starting in 1995, the Survey of Consumer Finances (SCF) asked respondents about the amount of their desired savings earmarked for unplanned emergencies. This question was designed by one of the authors of this paper 
to explicitly measure precautionary savings. ${ }^{3}$ After showing that responses to this question vary with measures of income risk faced by the household, we show that in the aggregate, reported precautionary savings comprise less than eight percent of total wealth. The sample of business owners reports having less than four percent of their total wealth as precautionary savings while non-business owners report having around ten percent of their wealth as precautionary savings. In summary, our two methods for estimating the importance of precautionary savings yield strikingly similar results. Whether using regression analysis or examining direct reports of precautionary savings from survey questions, we find that precautionary savings explain less than ten percent of total wealth holdings.

The work in this paper is the first to bridge the gap between the work of Carroll and Samwick (1997, 1998) and Kazarosian (1997), which show sizeable effects of precautionary savings, and the literature that finds small effects (Guiso, Jappelli, and Terlizzese (1992), Skinner (1988), Hrung (2000), Engen and Gruber (2001) and Lusardi (1998)). In the final portion of the paper, we discuss how these studies which find small estimates of precautionary savings have implicitly controlled for differences between non-business owners and business owners either by excluding business owners from their samples or by excluding business wealth from their measure of household savings. Overall, we conclude that, when analyzing the importance of precautionary savings using micro data sets, researchers have to properly account for differences in saving motives between business owners and non-business owners. When differences cannot be accounted for, researchers should exclude business owners from their sample.

\footnotetext{
${ }^{3}$ See Kennickell and Lusardi (2004) for detail.
} 
The paper is organized as follows. In section 2 we review the standard approach to estimating the economic importance of precautionary savings. In section 3 we use data from the PSID to demonstrate the apparent importance of precautionary savings on a pooled sample of business owners and non-business owners. In section 4 we show that the results in section 3 are an artifact of pooling together different groups of households. Within both groups taken separately, we find at best small evidence of precautionary savings. Moreover, once we properly account for differences between business owners and non-business owners, we no longer find precautionary savings to be a sizeable component of aggregate wealth accumulation in the pooled sample. In section 5, we introduce the SCF data and review the evidence provided by the survey question designed to directly measure precautionary savings. In the final section we summarize our findings and discuss how accounting for differences between business owners and non-business owners is important for many empirical studies of household consumption and saving behavior beyond the analysis of precautionary savings.

\section{Estimating the Importance of Precautionary Savings}

Intertemporal models of consumption/saving behavior under uncertainty predict that agents accumulate wealth to insure themselves against risk (Deaton (1991), Carroll (1992, 1997)). For the most part, the precautionary saving literature has focused its attention on the relationship between labor income risk and wealth accumulation. ${ }^{4}$ All else equal, households who face more labor income risk should accumulate more wealth to insure themselves against unexpected low income realizations.

\footnotetext{
${ }^{4}$ Labor income risk is only one of the many different risks faced by households. Other risks include, for example, health and longevity. As with the bulk of empirical work on precautionary savings, the focus in this paper is on examining the relationship between non-capital income risk and household wealth accumulation. Given that our attention will be on heads of households aged 25-50, labor accounts for most of non-capital income, and labor income risk is likely to be the most important risk these households face.
} 
Using calibrated theoretical models, several authors have calculated that precautionary savings can explain as much as fifty percent of total wealth in the US economy (Skinner (1988), Caballero (1990, 1991), Carroll (1992), and Gourinchas and Parker (2002)). Existing empirical estimates using micro data have yielded mixed results, but studies such as Carroll and Samwick (1997, 1998) and Kazarosian (1997) have confirmed that precautionary saving is the leading motive to accumulate wealth and can explain roughly half of the total wealth of US households.

The empirical strategy of estimating the importance of precautionary savings using micro data is based on the following specification: ${ }^{5}$

$$
\ln \left(W_{i t}\right)=\alpha_{0}+\alpha_{1} \sigma_{i t}^{\text {permy }}+\alpha_{2} \sigma_{i t}^{\text {transy }}+\alpha_{3} \ln \left(y_{i t}\right)+Z_{i t} \beta+u_{i t}
$$

where $\ln \left(W_{i t}\right)$ is the $\log$ of a measure of household $i$ 's wealth in period $t, \ln \left(y_{i t}\right)$ is the $\log$ of a measure of household $i$ 's permanent income in period $t, \sigma_{i t}^{\text {permy }}$ and $\sigma_{i t}^{\text {transy }}$ are, respectively, measures of the variance of permanent shocks to household i's income and the variance of transitory shocks to household $i$ 's income. The $Z$ vector includes demographic characteristics of household $i$ in period $t$ including age, age squared, gender, race and marital status. The controls are included to capture potential differences in preferences across households and the hump-shaped profile of wealth over the life-cycle.

According to the precautionary savings model, wealth is a function not only of permanent income, but also of uninsurable risk faced by the household. Almost all empirical studies designed to estimate the importance of precautionary savings using micro data proxy uninsurable risk with either the variance of income (Carroll and

\footnotetext{
5 This specification is the one used by Carroll and Samwick $(1997,1998)$ and is similar to specifications used by Kazarosian (1997), Lusardi (1998) and Carroll, Dynan, and Krane (2003).
} 
Samwick (1997, 1998)), the variance of consumption (Dynan (1993)), or they exploit actual job loss or expectations of future job loss (Lusardi (1998) and Carroll, Dynan and Krane (2003)). In this paper, we follow Carroll and Samwick $(1997,1998)$ by using panel data to distinguish between the variance of permanent and transitory shocks to income. Since both permanent income and the variance of income are measured with considerable amount of error in micro data, we instrument these variables using controls such as, but not limited to, occupation and industry dummies. The testable implication then becomes whether households in those occupations and industries facing more volatile income streams accumulate more wealth to shield themselves against uninsurable shocks to income. ${ }^{6}$

The empirical work using this specification faces several challenges. First, it is not clear which measure of wealth to use in the regressions since wealth components differ in term of their liquidity and substitutability. For example, wealth accumulated for retirement or bequest motives can also serve to buffer shocks to income. Second, there are many differences in preferences and individual characteristics that should be accounted for when measuring either household wealth or income risk. Third and most importantly, researchers need to find some observable and exogenous sources of income risk that vary enough among the population to be able to estimate the effect of risk on wealth (Browning and Lusardi (1996)).

In the following section, we make use of the specification described in (1) to show that, while the empirical estimates for precautionary savings seem very high, these

\footnotetext{
${ }^{6} \mathrm{We}$ realize that there has been a growing literature that suggests occupation may not be a valid instrument given that risk-averse households may accumulate more wealth and also choose occupations with safe income streams (see FuchsSchündeln and Schündeln (2005)). We address this issue in section 3.2.
} 
estimates, in fact, tell us little about the strength of the precautionary saving motive among US households.

\section{Data and Empirical Work}

\subsection{Baseline Analysis}

We perform the empirical work using data from the PSID. As in Carroll and Samwick $(1997,1998)$, we use wealth data from the 1984 PSID wave. Also, like Carroll and Samwick, we use income data from the 1981 through 1987 waves to construct measures of the permanent and transitory variance of income. ${ }^{7}$ To broaden our analysis, we also use data from the 1994 PSID wealth supplement. In doing so, we construct the corresponding permanent income and variances of income using income data from 199197. The use of more than one cross-section of wealth data allows us to control for macroeconomic conditions in different time periods as well as to check the robustness of results over time.

To partially overcome the problem that wealth accumulated for other reasons (i.e., retirement or bequests) can serve to insure against shocks to income, we restrict our sample to households whose head is between the ages of 26 and 50 in the year the wealth is measured. ${ }^{8}$ According to the precautionary saving model of Carroll $(1992,1997)$, Carroll and Samwick (1997, 1998) and Gourichas and Parker (2002), the precautionary saving motive (with respect to labor income risk) is the dominant motive to save up to until age 45-50. After the age of 50, the predominant reason households save is to fund consumption during retirement. A detailed description of other restrictions in

\footnotetext{
${ }^{7}$ We construct the measures of the permanent and transitory income variances using the approach outlined by Carroll and Samwick (1997). Details of the calculations are available from the authors upon request.

${ }^{8}$ As a robustness test, we redid our whole analysis including non-retired households aged 25-57. This change did not change the main results. We use the more restrictive age range for our analysis in order to: 1) give precautionary savings the best shot to explain household wealth accumulation and 2) be consistent with the existing literature.
} 
constructing our final sample is reported in the Data Appendix. Appendix Table A1 includes descriptive statistics of the main variables we use in our empirical work. Our final sample includes 2,144 households.

The controls we use in our empirical work include the following demographics: age, age squared, race, gender, marital status, and education attainment. ${ }^{9}$ In addition, we exploit the panel dimension of the PSID to control for past income and wealth shocks experienced by households. Specifically, we include a year dummy and dummies for whether the head of the household was unemployed during the year when the wealth data were collected and any time during the prior four years (1980-1983 or 1990-1993). Households who are more likely to face high income risk are also more likely to have been hit by past negative income shocks, and this may weaken the estimated relationship between wealth and risk. We also include dummies for past positive shocks, such as having received inheritances or other lump sum payments.

We construct permanent income by taking the average of non-capital income over the relevant sample period (1981 through 1987 or 1991 through 1997). Non-capital income is defined as the sum of the head's labor income, the spouse's labor income (if a spouse is present), the labor income of all other household members, and all transfers received by the household (excluding any capital income components). All dollar amounts are in 1997 dollars.

For comparability, we follow the procedure of Carroll and Samwick (1997) to compute the variances of permanent and transitory shocks to income. Since both

\footnotetext{
9 As a robustness check, we also included controls for the growth of household income during the seven-year period (1981 - 1987 or 1991 - 1997). In some specifications, we also instrumented for income growth. Regardless of the specification, the growth in income was always a strong predictor of household wealth. Those with steeper income profiles held lower wealth, conditional on their level of permanent income. However, in no instance did the inclusion of our income growth measures affect our estimates of the importance of precautionary savings.
} 
permanent income and the variances of permanent and transitory income are measured with error, we instrument for these variables using a large set of variables. As suggested by Carroll and Samwick $(1997,1998)$, we use occupation dummies and these dummies interacted with age and age squared, as well as industry dummies. In addition, we use the unemployment rate in the county of residence during the prior year, the variance in the county unemployment rate over the sample period, and a dummy for whether the head belongs to a union. Other studies have used the variation in unemployment across regions to instrument for the variance of income (Lusardi (1997) and Engen and Gruber (2001)). Furthermore, Gottschalk and Moffitt (1994) show that the increased earnings instability after the 1980 s is correlated with changes in unionization.

Table A2 in the Appendix shows our estimates of the variances of permanent and transitory income by one digit occupational categories. There are sizeable differences in income variances across occupations. For example, self-employed managers are more likely to experience a shock to both their permanent and transitory components of income than managers employed in firms. The estimates reported in Table A2 match closely the estimates reported by Carroll and Samwick (1997).

The measure of wealth we use initially is total net worth, which is defined as the sum of checking and saving accounts, bonds, stocks and mutual funds (including IRAs), home equity, other real estates, business equity, cars and other vehicles, and other assets, minus the value of all debts. Since we use logs, we exclude households who have negative or zero net worth in our sample, which amount to a little more than five percent of our sample. In the following subsections, we avoid this sample restriction by using wealth-to-income ratios as our dependent variable. In this case we do not exclude any 
additional households from our analysis. As we will show below, our key results are unaffected by this restriction.

Empirical estimates of equation (1) are reported in Table 1. For brevity, only the coefficient estimates of the variances are reported. Both estimates of the income variances are statistically significant and show that, as predicted by the theory, higher income risk leads to higher wealth holdings. According to these estimates, the precautionary saving motive is very important. We perform two experiments to provide context to the magnitude of the coefficient estimates. First, we assume that households move from an occupation with low income risk (professionals, with an estimated variance of permanent income shocks of 0.013 and an estimated variance of transitory shocks of 0.040 ) to an occupation with high income risk (operatives and laborers, with an estimated variance of permanent shocks of 0.019 and an estimated variance of transitory shocks of 0.059). ${ }^{10}$ The movement across those occupational categories increases household wealth by thirty-four percent (all else equal). If we move a manager who is employed by a firm (estimated permanent and transitory variances equaling 0.017 and 0.030 , respectively) to being a self-employed manager (estimated permanent and transitory variances equaling 0.027 and 0.087 ), we predict that household's wealth would increase by fifty-three percent.

As a second way to gauge the magnitudes of the coefficients in Table 1, we compute the total amount of aggregate wealth explained by precautionary savings by eliminating all income risk, i.e., setting both variances to zero. After doing so, we can calculate how much wealth households would accumulate when facing no income risk

\footnotetext{
${ }^{10}$ See Table A2.
} 
and compare that amount to the estimates when income risk exists. ${ }^{11}$ As reported in Table 1, we find that almost half of total net worth is accounted for by precautionary savings. Ninety-five percent confidence bands around our estimate suggest that the share of total wealth explained by precautionary savings ranges from about forty-one to sixty percent. ${ }^{12}$ This approach is very similar to the procedure used by Carroll and Samwick (1997, 1998), who found that about half of wealth is explained by precautionary motives. Thus, our estimates are consistent with the existing literature which estimates the importance of precautionary savings by pooling together households regardless of whether or not they own a business.

However, zero income risk represents a rather extreme case. Therefore, we also redo the experiment setting the variances to the minimum mean across occupations as found in Table A2 (i.e., setting the permanent variance to 0.0079 and the transitory variance to 0.0305$)$. Under this experiment, the amount of total wealth accounted for precautionary saving is twenty-five percent. Ninety-five percent confidence bands around this estimate suggest that the share of total wealth explained by precautionary savings ranges from about seventeen to thirty-four percent.

\subsection{Sensitivity Analysis}

Before showing that the above results disappear when we control for differences between business owners and non-business owners, we show that these results are generally robust to a variety of alternative specifications. In essence, we want to show

\footnotetext{
11 To do this, we use the estimates from (1) to predict log wealth for each household. We then predict log wealth for each household setting the variances of permanent and transitory incomes to zero. To get the estimated percent of wealth explained by precautionary savings, we take the difference between the predicted log wealth with and without the variances set to zero for each household and then average over all households. We also repeat this procedure setting the value of the variances to the minimum mean value across occupations as explained later in the text.

1295 percent confidence bands were bootstrapped using 1,000 repetitions.
} 
that what is driving the result is the pooling of non-business owners and business owners together rather than the choice of samples, measures of wealth and income variances, and set of instruments.

First, as already suggested by several researchers (Lusardi (1997) and FuchsSchündeln and Schündeln (2005)), workers can self-select into jobs according to their coefficient of risk aversion. If such selection exists, the use of occupation and industry dummies as instruments for the variance is invalid. We have therefore tried a different set of instruments. Specifically, our instrument set includes only the county unemployment rate, the variance of the county unemployment rate, and dummies for whether the head belongs to a union, whether the spouse works, whether there are other earners in the household, and whether the worker is hourly paid.

While these alternative instruments have some predictive power for the variance of income, it has lower power than when occupation and industry dummies are included. The results of this specification are shown in Table 2, column I. Using this new instrument set, the importance of precautionary savings in explaining aggregate wealth holdings is diminished. Instead of explaining almost one-half of total wealth accumulation, the estimates with the modified instrument set suggest that approximately one-quarter of total wealth accumulation is explained by precautionary motives when setting the variances to zero and thirteen percent when setting the variances to the lowest mean value. While the share of precautionary wealth is smaller in this case, it is still sizeable.

To further evaluate the robustness of results, we have investigated a different measure of the variance of income. Rather than calculating the variance of permanent 
and transitory shocks to income-a procedure that involves making rather restrictive assumptions-we have worked with a measure of the total income variance faced by households. To compute this measure, we regress the log of non-capital income on some exogenous characteristics such as age, age squared, race and gender. We calculate the variance of the residual from that regression over the sample period (1981-87 or 1991-97) for each household. We then use this measure to replace both the permanent and transitory income variances in our estimation of (1). We re-estimate (1) using both the original instrument set and the second instrument set discussed above (excluding the occupation and industry dummies). Results are shown in Table 2, Columns II and III, respectively. ${ }^{13}$ As in Table 1, those facing higher income risk accumulate higher amounts of wealth, sometimes as much as fifty percent of total wealth. Thus, our main results hold true in this specification as well and are not sensitive to the assumptions we have made when calculating the permanent and transitory variances of income.

The use of the log of wealth poses another potential problem. While the distribution of wealth is very skewed and we need to worry about the influence of very rich households, using the log transformation leads us to exclude a sizable number of households with negative or zero wealth from the sample. This exclusion is hardly exogenous. In fact, high risk households may get hit by shocks that deplete their resources and push them into negative wealth. In this case, the selection of the sample can bias our estimates. There is another consideration when working with positive net worth only; it could be that the precautionary saving motive prevents households from going heavily into debt, but they still would not hold positive wealth. In other words, the precautionary saving motive may simply limit the amount of borrowing that households

13 As above, both instrument sets have strong power in predicting this new variance measure. 
would otherwise undertake. Since we eliminate households in debt, we may end up incorrectly calculating the amount of precautionary savings undertaken in the economy. ${ }^{14}$

To potentially overcome this problem, we have used the ratio of wealth over permanent income as our dependent variable and retain the observations with zero or negative net worth in the sample. To limit the effects of outliers, we have trimmed the distribution and excluded the observations at the top and bottom two percent of the distribution of the wealth to permanent income ratio. As reported in column IV of Table 2 , this specification implies that fifty-seven percent of aggregate wealth is explained by the precautionary savings motive when setting the variances to zero and to twenty-five percent when setting the variances to the lowest mean values.

In summary, the estimation of (1) is robust to many potential criticisms. Specifically, changing the instrument set to exclude occupation and industry dummies, using different measures of the variance of income, and using the wealth-to-income ratio as opposed to the $\log$ of wealth as our dependent variable all yield results that show that precautionary savings explain at least one-quarter and as much as sixty percent of total wealth accumulation.

\section{The Importance of Business Owners}

One of the problems in estimating the types of regressions described above is that they pool together distinct sub-groups within the population. Mixing together households that own a business (or are self-employed) with other households can be problematic to the extent that business owners as a group face higher risks and accumulate larger

\footnotetext{
${ }^{14}$ Many theoretical models of precautionary savings impose liquidity constraints and prevent households from going into debt (see Deaton $(1991,1992)$. The inability to borrow makes the precautionary saving motive stronger; if households cannot borrow when hit by shocks, there is stronger need to accumulate a stock of precautionary wealth.
} 
amounts of wealth for reasons unrelated to precautionary saving. The large positive estimates of precautionary savings documented in the previous section may simply be an artifact of pooling together business owners and non-business owners.

Business owners have nearly three times as much wealth (Table A1) and experience nearly twice as much labor income risk (Table A3) as non-business owners. We first examine whether business owners hold more wealth than other households after conditioning on permanent income. To show the relationship between wealth and permanent income between business owners and non-business owners, we regress the log of household wealth on a cubic in the log of household permanent income and a business ownership dummy for households in our PSID sample. ${ }^{15}$ The coefficient on the business ownership dummy is 1.24 (p-value $<0.01$ ). This implies that, conditional on measured permanent income, business owners on average accumulate 124 percent more wealth than their non-business owning counterparts.

There are many reasons why business owners hold more wealth than non business owners aside from the fact that they face higher income risk. For example, business owners are much less likely to have private pensions (Gustman and Steinmeier, 1999). Data from the Health and Retirement Survey (HRS) show that approximately fifty-four percent of non-business owners are covered by a private pension. The comparable number for business owners is only thirty percent. Upon retirement, the ratio of pension wealth (excluding social security) to non-pension wealth is about twenty-five percent for the average household (Gustman, Mitchell, Samwick and Steinmeier (1999)). As a result, business owners have to accumulate much more non-pension wealth to sustain

\footnotetext{
15 As discussed above, our measure of wealth does not include public or private pensions. Up through 2001, the PSID did not collect significant information on private pensions.
} 
consumption through their retirement years. Most micro data sources like the PSID exclude pension wealth from their measures of private wealth; this fact alone could explain a large fraction of the difference in wealth levels conditional on permanent income.

Additionally, business owners are more likely to report that they would like to leave a bequest to future heirs (Hurst and Lusardi (2004)). This is not surprising given that business owners often want to pass their business directly to their heirs. Business owners may also need to maintain large amounts of working capital both to deal with the necessities of their business and to maintain effective control over the business. Most importantly, if households are compensated for taking greater risks with higher returns, it is again not surprising that business owners have higher wealth than non-business owners for given levels of permanent income. If researchers do not properly control for all of these differences between business owners and non-business owners, one would expect to find a strong positive association between income risk and wealth even in an environment with no precautionary motives.

Lastly, as mentioned above, conditional on measured permanent income, business owners have higher wealth than non-business owners. However, it is possible that given the way permanent income is usually measured, it is an appropriate measure of lifetime resources for non-business owners, but it is an inappropriate measure of lifetime resources for business owners. If average non-capital income is an underestimate of actual permanent income for business owners, business owners will be observed as having higher wealth conditional on measured permanent income even if they do not have higher wealth conditional on actual permanent income. Given tax avoidance 
incentives, tax evasion incentives, and the difficulty in differentiating between labor and capital returns for business owners, there is reason to believe that measured permanent income is understated for business owners. We explore this hypothesis in depth in subsection 4.2.

\subsection{Estimating Precautionary Savings among Non-Business owners}

Our hypothesis is that the empirical estimates of precautionary savings from Section 3 (and from much of the existing literature on precautionary savings) are large because they pool together business owners and non-business owners. To test this hypothesis, we begin by estimating (1) on a sample which only includes households who do not own a business in year $t$ (sample size $=1,729)$. Otherwise, the sample is exactly the same as the one used for the estimates presented in Table 1. Our dependent variable remains the log of total net worth. The permanent and transitory variances are computed as above and the vector $\mathrm{Z}$ of controls is unchanged. Lastly, we instrument the variance of permanent income shocks, the variance of transitory income shocks, and the level of permanent income with the main instrument set described in section 3 .

Table 3 shows that, compared to the results in Table 1, the coefficients on both income variance measures fall dramatically in magnitude and are no longer statistically different from zero. To gauge the overall importance of precautionary savings under these estimates, we repeat the experiments in Section 3. First, we suppose that households move from an occupation with low income risk (professionals) to an occupation with high income risk (operatives and laborers). Under this experiment, household wealth would barely change at all. Recall that the comparable thought experiment using the 
coefficients estimated in the pooled sample (from Table 1) was an increase of thirty-four percent.

Second, we examine how much of total wealth held by non-business owners is explained by precautionary savings. Assuming that households face zero or very low risk (as in the procedure described in Section 3), the estimation implies that precautionary savings explain -4.1 percent of total wealth holdings when setting the variances to zero and -1.4 percent when setting the variances to the lowest mean value. Note that these estimates are not statistically different from zero. The bootstrapped 95 percent confidence bands for the first estimate (zero variances) are minus forty percent to twelve percent and for the second estimate (lowest mean value) are minus nine to seven percent. In other words, the confidence bands from these estimates imply that at most twelve percent of total wealth held by households under the age of fifty is explained by precautionary savings.

The result of this specification is striking. It says that among non-business owners (between eighty percent and ninety percent of the population), there is, at best, only a small systematic relationship between labor income risk and household wealth holdings. Moreover, compared to values reported in the empirical and theoretical papers mentioned above, our estimates are much smaller; at most twelve percent of total wealth held by households under the age of fifty is explained by precautionary savings.

Another set of variations serves to emphasize just how critically the importance of the precautionary saving motive hinges on the inclusion of business owners in the sample used for the estimation. One might argue that because business owners are, on average, wealthier than other households, the estimates may simply capture different behavior 
among the wealthy. To assess whether we are simply measuring wealthy or successful households when considering business owners, we cut the data in two additional ways. First, we remove from our sample those households in the top twenty percent of the income distribution (leaving us with 1,716 observations). Second, we exclude from the sample households who own stocks (for a sample of 1,238 observations). In both cases, we find that precautionary savings continue to explain a large (and statistically significant) portion of total household wealth. Specifically, for the sample of households in the bottom eighty percent of the income distribution, forty percent of wealth appears to be explained by precautionary reasons. In the sample of non-stock owners, thirty-five percent of wealth appears to be explained by precautionary reasons. ${ }^{16}$ Thus, in both cases substantial fractions of wealth can be explained by the precautionary motive, arguably because each sample includes a substantial fraction of business owners; eighteen percent of the lower income households and seventeen percent of non-stock owners report owning a business.

In conclusion, there is no evidence of precautionary savings driving large amounts of wealth accumulation in the sample of non-business owners. Moreover, the estimates are likely much closer to zero than they are to fifty percent.

\subsection{The Importance of Precautionary Savings among Business Owners}

In the above subsection, we documented that the estimated importance of precautionary savings is severely mitigated if we exclude the business owners from our sample. However, this does not imply that precautionary savings are not important. It may be that business owners respond strongly to labor income risk. Their response to

\footnotetext{
${ }^{16}$ For simplicity and because the sample sizes change, we only consider setting the values of the variances to zero.
} 
such risk, in turn, may give rise to large amounts of wealth in the economy, a point previously noted in the work by Carroll and Samwick $(1997,1998) .{ }^{17}$

To probe the precautionary motives of business owners further, we re-estimate (1) for this group alone. The results of this estimation are shown in column I of Table 4. Indeed, the coefficients on both variance measures are positive and statistically different from zero. Using the same procedure as above and setting the variances to zero, we find that thirty-three percent of wealth among business owners can be explained by precautionary motives. When setting the variances to the lowest mean value, we find that precautionary savings account for twenty-three percent of wealth. These effects are also statistically different from the non-business owners sample.

On the surface, this number appears large. But, as with pooling different types of households in the full sample, the numbers reported in column I of Table 4 could result from other reasons than the desire to insure against risk. Specifically, those business owners who take more risks should, on average, be compensated with higher returns. The relationship between wealth and income risk could simply capture the risk-return tradeoff rather than the strength of the precautionary saving motive among business owners. ${ }^{18}$

To address this issue, we first assess how robust the findings in column I are to alternate specifications. One simple change to the estimation is to exclude business

\footnotetext{
17 As noted above, Carroll and Samwick (1998) find that over fifty percent of wealth for households under the age of 50 can be accounted for by precautionary motives. However, they do note that, when they exclude farmers and the self-employed from their sample, their estimates suggest that precautionary motives explain essentially zero percent of aggregate wealth holdings. They state that: "(Their) preferred interpretation of these findings is of course that the farmers and the self-employed provide exactly the same kind of variation in the independent variable that is very valuable to identify the coefficient on uncertainty, and hence, these groups should remain in the sample" (page 415). In fact our paper shows that business owners have high wealth (compared to non business owners) for other reasons aside from precautionary motives. A contribution of this paper is to show that, even within the sample of business owners, the relationship between risk and wealth proxies for something other than precautionary motives.

${ }^{18}$ Note that since we consider those households who are business owners in the years when the wealth data was collected (1984 or 1994), we are implicitly considering only those business owners who either started in that year or that started earlier and survived. The survival bias further strengthens the relationship between wealth and labor income risk in the sub-sample of business owners.
} 
wealth from our measure of total net worth. If equity in private businesses is illiquid, the returns to business ownership may show up in higher business wealth. ${ }^{19}$ Moreover, it seems implausible that business owners would hold their precautionary wealth in their businesses: Income streams from the business and the value of the business are positively correlated. For savings to provide insurance, we expect business owners to hold at least a portion of their precautionary reserves outside of their business.

In column II of Table 4, we report the estimates of (1) for the business owners sample where the dependent variable is now the log of non-business wealth. Under this specification, the estimated impact of the precautionary saving motive falls by more than half (from thirty-three percent to fifteen percent when setting the variances to zero and from twenty-three to ten percent when setting the variances to the lowest mean value). The degree to which non-business wealth responds to risk is now fairly small among business owners.

Another important point concerns the estimation of permanent income. As mentioned before, permanent income is measured by averaging non-capital income for a given household over the sample period. While non-capital income is likely to be a sufficient measure of compensation for non-business owners, the situation is not so straightforward for business owners. There are three important factors in this difference. First, tax evasion may drive some business owners to under-report their labor income (by far, the most important component of non-capital income). Second, legal tax avoidance drives some business owners to retain part of their compensation within the business. ${ }^{20}$

\footnotetext{
19 We are aware that business owners could effectively liquidate the returns to their business by holding lower nonbusiness wealth. The exclusion of business wealth from our measure of net worth is meant to explore the robustness of our estimates to plausible alternative specifications.

${ }^{20}$ See Holtz-Eakin, Joulfaian and Rosen (1994), who also emphasize there are many tax incentives in business ownership.
} 
Lastly, tax evasion and tax avoidance aside, it is hard to specify and measure the actual labor return from business ownership; the part of business income attributed to capital and to labor is inevitably arbitrary in many cases. ${ }^{21}$ This mis-measurement is problematic for this sort of analysis given that the return to the investment of business owners (i.e., their total compensation) is likely correlated with the underlying risk of the project.

According to standard consumption theory, household consumption is a valid measure of a household's permanent income. While labor income may be underreported for business owners, there is no reason to believe that consumption for business owners will be seriously mis-measured relative to the consumption of non-business owners. As a potentially better proxy for the lifetime resources of households, we use consumption in lieu of non-capital income in the estimation of $(1) .^{22}$

The PSID provides information on food consumption at home (including food stamps) and food outside the home. Although the sum of these two measures is only a limited proxy for total nondurable consumption, many studies have used food consumption to test the predictions of the theory and have found that food consumption often displays characteristics similar to non-durable consumption (Lusardi (1996), Hurst (2004)). We take the average of the sum of food at home, food away from home, and food stamps over the sample period as a proxy for permanent income and use it as a proxy for $y_{i t}$ in (1) to test the sensitivity of the model to our original definition of permanent income. We instrument for the variances of income and average food consumption using the same set of variables as before.

\footnotetext{
${ }^{21}$ Note that a large portion of labor earnings for business owners are simply imputed within large micro surveys such as the PSID or the Current Population Survey.

22 See, among others, Meyer and Sullivan (2003) who also use consumption as a proxy for permanent income.
} 
The results of this regression are reported in Table 4 (column III). The coefficients of the variance measures are no longer statistically different from zero and are much smaller in magnitude, compared to those found in Table 1. Using the same procedure as outlined in Section 3, we find that precautionary motives explain a little more than eight percent of total wealth within the sample of business owners (the equivalent number for setting the variances to the lowest mean value is a little over six percent). The ninety-five percent confidence bands on these estimates range from roughly negative three percent to twelve percent. Of course, these values are only crude measures of the importance of precautionary savings. These experiments aim to show that the correlation between wealth and risk among business owners may capture something else than simply precautionary savings. Note, however, that our results are robust to a variety of changes. Whether we use different instrument sets, different measures of the variance of income, or the self-employed rather than business owners (discussed below), our key results do not change.

When we return to the pooled sample and re-estimate (1) using the log of nonbusiness wealth as the dependent variable and using food consumption as the measure of permanent income (and keeping everything else the same), we find results that are dramatically different from those reported in Table 1 (see Table 5). Notably, the implied share of precautionary wealth explained by precautionary motives decreases from fortyseven percent to less than ten percent. These results are striking. When pooling together non-business owners and business owners and using total wealth which includes business equity, we find that precautionary savings explains nearly half of total wealth accumulation. However, this is simply an artifact of pooling together different groups of 
households without accounting for their differences. When we control for the presence and importance of business owners, we find estimates of the impact of precautionary savings in explaining aggregate wealth holdings to be lower than in much of the existing literature. As noted above, for non-business owners, which comprise over eighty-five percent of the sample, we find that the precautionary motive explains at best twelve percent of total wealth holdings (as measured by the upper bound of the 95 percent confidence interval).

One may argue that splitting the sample by business owners is not the best way to cut the data. Instead, we could split the sample by whether or not the household head is self-employed. As noted by Carroll and Samwick (1997), results are sensitive to the inclusion of the self-employed. Only sixty-three percent of business owners report that they are self-employed when asked about their primary job. ${ }^{23}$ Moreover, only about two-thirds of those who report being self-employed report owning a business.

In Table 6, we report the results of estimating (1) on a sample of households who are not self-employed and a sample of households who report being self-employed. The results are even stronger than those presented in Tables 3 and 4. Specifically, for households who are not self-employed, precautionary motives only explain less than two percent of wealth holdings. For those who report being self-employed, precautionary motives explain only slightly over eight percent of total wealth. ${ }^{24}$ The regressions reported in Table 6 have the log of total net worth as the dependent variable and use average non-capital income as the measure of permanent income. In other words, the

\footnotetext{
${ }^{23}$ Some business owners earn their primary labor income from a source other than the business. For these households, the business provides either a supplement to their primary labor income or a return on capital only.

${ }^{24}$ If, rather than setting the variances to zero, we set the variances to the lowest mean value, we find that the share of precautionary savings among those who are not self-employed is basically zero and among the self-employed is $6 \%$.
} 
regressions are analogous to the regression reported in Table 1. This shows that the results are clearly driven by pooling. Considering the self-employed and the non-self employed together leads to large estimates of the percent of wealth explained by precautionary savings. However, when the sample is split by self-employment status, there is little evidence of a sizeable precautionary motive within each sub-sample.

Does our estimation imply that one cannot run regressions on pooled samples that include both non-business owners and business owners (or self-employed households)? According to our work, if researchers do run pooled regressions (as done in the majority of the empirical work on precautionary savings), they need to account for differences between these two groups. At a minimum, researchers should account for more appropriate measures of permanent income and should examine the robustness of their results by excluding business wealth from their measure of potential precautionary savings. They should further model the other reasons why business owners accumulate wealth because that may lead to an artificial correlation between wealth and income risk. In surveys where such data is not provided, we suggest dropping the business owners (or the self-employed) from the sample.

In summary, we show that the standard estimates of the importance of precautionary savings in explaining total wealth accumulation are fragile. Within both the sample of business owners and non-business owners, our estimates of the magnitude of precautionary savings are less than ten percent. While this amount is still sizable, it is much smaller than the estimates reported by other authors using the same estimation procedure. In the next section, we explore a potentially more robust method to measure the amount of precautionary savings within the population. 


\section{An Alternative Approach to Estimating Precautionary Savings}

As the previous sections show, it is hard to disentangle the amount of precautionary savings using the estimation techniques described above. We propose an alternative approach to evaluate the importance of precautionary savings, which relies on a direct question about desired precautionary wealth from the Survey of Consumer Finances (SCF). Starting from 1995, the following question has been asked to all SCF respondents:

"About how much do you think you and your family need to have in savings for unanticipated emergencies and other unexpected things that may come up?"

This question was specifically designed to get respondents to elicit the amount of desired precautionary savings. ${ }^{25}$ In other words, the question was intended to measure what is the equilibrium level of desired precautionary savings due to the fact that future income streams and consumption needs are uncertain. Prior to being added to the SCF, the question was thoroughly pre-tested.

The question has been extensively analyzed by Kennickell and Lusardi (2004). They show that responses to this question tend to mimic the customary pattern of wealth holdings over the life-cycle and across demographic groups. For example, young households, who have low wealth, tend to report low amounts of precautionary savings and, for this group, precautionary savings is almost always less than total reported gross wealth. More importantly, Kennickell and Lusardi (2004) show that responses to this question are correlated with various measures of risk, including income, longevity and

\footnotetext{
${ }^{25}$ The wording reflects the responses households give when asked open-ended questions about motives to save. Other data sets, such as the Dutch CentERdata and the German Save, have questions about precautionary savings that have the same wording. See Borsch-Supan and Essing (2003). A similar question has now been added to the 2003 Italian Survey of Household Income and Wealth and the 2005 Dutch CentERdata Panel.
} 
health risk. Since the question is asked to all respondents with no age restrictions and does not specify an explicit source of risk, responses refer to all types of risk, not just labor income risk.

Another important feature of this variable is its behavior during the stock market boom. While total net worth increased sharply from 1995 to 1998 due to the increase in the price of stocks, the distribution of desired precautionary savings remained roughly the same in 1995 and 1998, as we would expect from the fact that neither labor income risk nor permanent income increased dramatically during that short time period.

To further assess the accuracy of the SCF self-reported measure of precautionary wealth, we restrict our SCF sample using the same criteria we use when constructing our PSID sample. Our goal is to see how our new measures of precautionary savings respond to permanent and transitory income variances, as predicted by the precautionary saving model. To do this, we estimate an equation similar to equation (1) described above, replacing the $\log$ of net worth with the $\log$ of desired precautionary savings. This specification allows us to examine directly whether households with higher income variances are also those that report higher amounts of precautionary wealth.

The one draw-back to this procedure is that the SCF is not a panel data set. This makes it impossible to measure income variance of a given household directly from SCF data. To overcome this problem, we combine data from two samples. We estimate the income variances using panel income data from the PSID (from 1991 to 1997). We then use the estimated coefficients from the PSID to construct an estimated measure of the variance of both permanent and transitory income shocks for households in the SCF. This procedure is possible because one can define the demographic variables and the 
occupation and industry dummies used as instruments comparably in the PSID and the SCF. For this method, we use demographics (age, age squared, marital status, race, gender and number of children) industry dummies, education and occupation dummies (and their interactions with age and age squared) to construct the transitory and permanent income variances. We measure permanent income in the SCF by using the measure of "normal" household income provided by SCF respondents (Kennickell and Lusardi (2004)). ${ }^{26}$

Estimates from this two-sample procedure are reported in Table 7. Column I reports the results from the full sample, while columns II and III, respectively, report the results when the sample is restricted to non-business owners only and then business owners only. ${ }^{27}$ As expected, desired precautionary savings are correlated with the variance of permanent and transitory income shocks in the total sample. Thus, higher income risk leads households to desire to hold higher amounts of precautionary wealth.

Considering the estimates using total net worth rather than desired precautionary savings in the first column of Table 8, we find that total wealth is also correlated with income risk in the total sample. However, when we exclude business owners from the sample, the estimates using total net worth indicates there is no longer evidence of precautionary savings in the non-business owners sample. Only business owners display a precautionary saving motive (Table 8 , column II and III). Results are similar to the estimates in the first part of the paper using PSID data, confirming that pooling business owners and non-business owners together leads to misleading estimates of the

\footnotetext{
${ }^{26}$ See the Data Appendix for a description of the SCF sample and the main variables used in the empirical work.

27 Standard errors have been corrected using a bootstrapping procedure with 1,000 repetitions. Standard errors for the SCF estimates need to be corrected both for fact that the variance measures are estimated using PSID data and the fact that missing data in the SCF are multiply imputed (see Data Appendix).
} 
precautionary saving motive. Estimates using desired precautionary savings (Table 7 Columns II and III) are instead indicative of a mild precautionary saving motive both among business owners and non-business owners and this is what we now turn to assess the quantitative importance of precautionary savings.

The advantage of the SCF data on desired precautionary savings is that we can simply look at the amounts reported by households. These values represent an upper bound to the value of precautionary savings against income risk since the question refers to all types of risk that household finds relevant. However, since we concentrate on young families only, income risk is likely to be the most considerable source of risk.

In our most preferred analysis, we simply examine the amount of reported precautionary wealth as a fraction of total net worth for SCF households. If the SCF question is measuring desired precautionary savings, as we have shown above, we can assess the overall importance of precautionary savings by directly examining the relative magnitudes reported by SCF households. Panel A of Table 9 reports mean and median values of desired precautionary savings in the total sample, the sub-sample of nonbusiness owners and the sub-sample of business owners only. These values highlight again the importance of business owners when assessing the importance of precautionary savings. Business owners desire a higher amount of precautionary savings than nonbusiness owners and these values are often quite high. Panel B of Table 9 reports the more relevant statistic, the ratio of desired precautionary savings to total net worth. Precautionary savings account for approximately seven percent of wealth in the full sample of households under the age of 50 in the SCF. Among business owners, 
precautionary savings account for approximately four percent, while among non business owners, precautionary savings account for ten percent of total net worth.

This analysis is consistent with our regression analysis outlined in the first part of the paper. These values show that a precautionary saving motive does exist among young families in the U.S. Thus, models of consumption/saving behavior should incorporate income risk into their theoretical framework. However, this motive does not give rise to large amounts of wealth. The precautionary saving motive can at best explain less than ten percent of total net worth.

Disentangling the importance of precautionary savings by using a measure of total net worth is very difficult both conceptually and empirically. The stock of wealth at a point in time is the result of precautionary accumulation, but it also includes (among other things) the return from taking risk, past and current portfolio choice, the shocks that have hit households. Estimates of precautionary savings from simple regressions of total wealth on proxies for risk are likely to be confounded by such factors.

\section{Conclusion}

Some of the papers in the literature on precautionary savings suggest that precautionary motives explain about half of total wealth, while other papers suggest a much smaller fraction. The results of this paper indicate that the high estimates of the importance of precautionary savings are driven by mixing two very different groups of households: business owners and non-business owners. Relative to the latter group, the former holds large amounts of wealth and also faces high income risk. Although pooling these two groups leads to very large estimates of the share of precautionary wealth out of 
total net worth, we show that, within these two groups separately, the estimated amount of precautionary savings is low.

Specifically, using a variety of different techniques and exploring two types of methodologies (estimating the effects of income risk using regression analyses and exploiting the answers to new survey questions), we find that precautionary motives explain less than ten percent of total wealth held by households under the age of 50 . For non-business owners, the $95^{\text {th }}$ percentile of our confidence band suggests that precautionary motives with respect to labor income risk explain no more than twelve percent of total wealth accumulation. This is not inconsistent with the theoretical work and simulation results of Carroll (1992) and, more recently, Irvine and Wang (2001).

Our results can explain and reconcile the widely different estimates of precautionary savings that are found using different micro data sets and across different countries. For example, Engen and Gruber (2001), Hrung (2000), Lusardi (1998), and Skinner (1988) all found rather modest estimates of the importance of precautionary savings. Upon examination, these findings are consistent with our results. Specifically, Engen and Gruber (2001) use data from the Survey of Income and Program Participation and consider a measure of gross financial assets that does not include business equity in their estimation of precautionary savings. Similarly, Hrung (2000) uses a measure of liquid financial wealth from the Continuous Work History Sample Panel of the U.S. Treasury that excludes business equity. Lusardi (1998) uses total net worth in her estimation, but her sample excludes the self-employed. Skinner (1988) uses the flow of saving rather than the stock of savings in his estimation of precautionary saving. Since he calculates saving by taking the difference between income and consumption, his 
estimates are less affected by the problem of pooling business owners and non-business owners together. All of the previous papers which found low estimates of the importance of precautionary savings in explaining wealth holdings within the U.S. economy have either explicitly or implicitly controlled for differences between business owners and non-business owners.

Our paper can also explain why the importance of precautionary saving varies a lot across countries. In fact, our results show one should be wary in making international comparisons. Since business owners in other countries may accumulate rather different amounts of wealth than in the US, estimates from foreign countries should be used with caution. For example, our results may explain why the estimates of precautionary savings in Italy and France (Guiso, Jappelli and Terlizzese (1992) and Arrondel (2002), respectively) are much lower than what is found in US data.

If precautionary motives are not overly important in explaining the wealth accumulation of younger households, why do these households save? While this question is not the specific aim of this paper, there is a large literature that documents the importance of liquidity constraints in affecting the financial behavior of younger households. For example, young households save to make a down payment to buy a home or for their children education. Additionally, once households purchase a home, they accumulate wealth each month by simply making their mortgage payments. In fact, over forty percent of wealth of young households is held in home equity. Lastly, many young households start accumulating wealth for retirement. Given the existence of liquidity constraints, the costs associated with extracting home equity, and life cycle 
saving motives, it is not surprising that precautionary motives with respect to labor income risk only explain a small portion of total wealth holdings of younger households.

Because the conceptual and measurement issues related to business owners have such a powerful effect on estimates of precautionary savings, we recommend that researchers control carefully for differences between business owners and other households. When this is not possible, business owners should be excluded from the sample.

Lastly, we want to stress that the results presented in this paper have implications for research well beyond precautionary savings. We show that, when examining household consumption or savings behavior, it is important to understand the difference between business owners and non-business owners. This is likely to be equally important in studies assessing the importance of bequest motives since business owners are more likely to leave bequests to their children. Similarly, business owners may play a critical role in assessing the offset of pension and private wealth; business owners are far less likely to have pensions than other households but may hold large amounts of wealth for reasons unrelated to pensions. 


\section{References}

Arrondel, Luc (2002), "Risk Management and Wealth Accumulation in France," Economics Letters, 74, 187-194.

Börsch-Supan, Axel and Lothar Essig (2003), "Household Saving in Germany: Results from the First SAVE Study," NBER Working Paper n. 9902.

Browning, Martin and Annamaria Lusardi (1996), "Household Saving: Micro Theories and Micro Facts," Journal of Economic Literature, 34, 1797-1855.

Caballero, Ricardo (1990), "Consumption Puzzles and Precautionary Savings," Journal of Monetary Economics, 25, 113-136.

Caballero, Ricardo (1991), "Earning Uncertainty and Aggregate Wealth Accumulation," American Economic Review, 81, 859-871.

Carroll, Christopher (1992), "The Buffer-Stock Theory of saving: Some Macroeconomic Evidence," Brookings Papers on Economic Activity, 2, 61-156.

Carroll, Christopher (1997), "Buffer Stock Saving and the Life Cycle/Permanent Income Hypothesis," Quarterly Journal of Economics, 112, 1-55.

Carroll, Christopher and Andrew Samwick (1997), "The Nature of Precautionary Wealth," Journal of Monetary Economics, 40, 41-71.

Carroll, Christopher and Andrew Samwick (1998), "How Important is Precautionary Saving?" Review of Economics and Statistics, 80, 410-419.

Carroll, Christopher, Karen Dynan and Spencer Krane (2003), "Unemployment Risk and Precautionary Wealth: Evidence from Households' Balance Sheets," Review of Economics and Statistics, 85, 586-604.

Deaton, Angus (1991), "Saving and Liquidity Constraints," Econometrica, 59, 12211248.

Deaton, Angus (1992), “Understanding Consumption,” Oxford: Oxford University Press.

Dynan, Karen (1993), “How Prudent Are Consumers?,” Journal of Political Economy, 101, 1104-1113.

Engen, Eric and Jonathan Gruber (2001), "Unemployment Insurance and Precautionary Saving," Journal of Monetary Economics, 47, 545-579.

Fuchs-Schündeln, Nicola and Matthias Schündeln (2005), "Precautionary Savings and Self-Selection - Evidence from the German Reunification 'Experiment,"” 
Quarterly Journal of Economics, 120 (3), 1085-1120.

Gottschalk, Peter and Robert Moffitt (1994), "The Growth of Earnings Instability in the U.S. Labor Market," Brookings Papers on Economic Activity, 2, 217-272.

Gourinchas, Pierre Olivier and Jonathan Parker (2002), "Consumption Over the Life Cycle," Econometrica, 70, 47-89.

Guiso, Luigi, Tullio Jappelli and Daniele Terlizzese (1992), "Earning Uncertainty and Precautionary Saving," Journal of Monetary Economics, 30, 307-338.

Gustman, Alan and Thomas Steinmeier (1999), "Effects of Pensions on Savings: Analysis with Data from the Health and Retirement Study," Carnegie-Rochester Conference Series, 50, 271-326.

Gustman, Alan, Olivia Mitchell, Andrew Samwick and Thomas Steinmeier (1999), "Pensions and Social Security Wealth in the Health and Retirement Study", in James Smith and Robert Willis (eds.), Wealth, Work ad Health, Innovations in Measurement in the Social Sciences, Ann Arbor: University of Michigan Press, 150-208.

Holtz-Eakin, Douglas, David Joulfaian and Harvey Rosen (1994), "Sticking It Out: Business Owner Survival and Liquidity Constraints," Journal of Political Economy, 102, 53-75.

Hrung, Warren (2000), "Is Retirment an Important Motive for Saving? An Investigation of Buffer-Stock Savings using Tax Data," Mimeo, Department of Treasury.

Hubbard, Glenn, Jonathan Skinner and Stephen Zeldes (1995), "Precautionary Saving and Social Insurance," Journal of Political Economy, 103, 360-399.

Hurst, Erik (2004), "Grasshoppers, Ants and Pre-Retirement Wealth: A Test of Permanent Income Consumers," NBER Working Paper n. 10098.

Hurst, Erik and Annamaria Lusardi (2004), "Liquidity Constraints, Household Wealth and Business Ownership," Journal of Political Economy, 112, 319-347.

Irvine, Ian and Susheng Wang (2001), "Saving Behavior and Wealth Accumulation in a Pure Lifecycle Model with Income Uncertainty," European Economic Review, $45,233-258$.

Kazarosian, Mark (1997), "Precautionary Saving - A Panel Study," Review of Economics and Statistics, 79, 241-247. 
Kennickell, Arthur (1998), "Multiple Imputation in the Survey of Consumer Finances," Proceedings of the Section on Business and Economic Statistics, 1998 Annual Meetings of the American Statistical Association, Dallas, Texas

Kennickell, Arthur and Louise Woodburn (1999), "Consistent Weight Design for the 1989, 1992, and 1995 SCFs, and the Distribution of Wealth," Review of Income and Wealth, 45, 193-215.

Kennickell, Arthur and Annamaria Lusardi (2004), "Disentangling the Importance of the Precautionary Saving Motive," NBER Working Paper n. 10888.

Lusardi, Annamaria (1996), "Permanent Income, Current Income and Consumption: Evidence from Two Panel Data Sets," Journal of Business and Economic Statistics, 14, 81-90.

Lusardi, Annamaria (1997), "Precautionary Saving and Subjective Earnings Variance," Economics Letters, 57, 319-326.

Lusardi, Annamaria (1998), "On the Importance of the Precautionary Saving Motive," American Economic Review, 88, 449-453

Meyer, Bruce and James Sullivan (2003), "Measuring the Well-Being of the Poor Using Income and Consumption," Journal of Human Resources, 38, 1180-1220.

Moskowitz, Toby and Annette Vissing-Jorgensen (2002). "The Private Equity Puzzle" American Economic Review, 92, 745-778.

Quadrini, Vincenzo (1999). "The Importance of Business Ownership for Wealth Concentration and Mobility," Review of Income and Wealth, 45, 1-19.

Quadrini Vincenzo and Victor Rios-Rull (1997), "Understanding the US Distribution of Wealth," Federal Reserve Bank of Minneapolis Quarterly Review, 21, 22-36.

Skinner, Jonathan (1988), "Risky Income, Life Cycle Consumption and Precautionary Saving," Journal of Monetary Economics, 22, 237-255. 


\section{DATA APPENDIX}

\section{PANEL STUDY OF INCOME DYNAMICS (PSID)}

\section{A.1 Sample selection}

We use data from the PSID in 1981-87 and 1991-97. To construct our final sample, we drop all households from the Survey of Economic Opportunity (SEO), which over-samples the poor, and from the added Latino sample. We also drop households with heads who were younger than 26 or older than 50 in 1981 (for the 1981-1987 panel) or 1991 (for the 1991-1997 panel). We drop households with invalid education, occupation or industry responses (including the unemployed and those who are not participating in the labor market) in those same years, as well as households where the head's marital status changes at any time during the period considered. We also drop households from the sample if the head or the wife changes during the period considered. Finally, to avoid the estimation of the permanent and transitory variances to be driven by a few households with extremely volatile incomes, we drop those households whose income in any year falls below $20 \%$ of the average household income during the time period. We also exclude observations with missing county unemployment rate. When using log wealth over permanent income, we also exclude those observations with zero or negative wealth.

\section{A.2. Definitions}

Net worth

Net worth is defined as the sum of all assets owned by the household at the time

of the interview. It includes money in checking or savings accounts and in IRAs; money market bonds; Treasury bills; bond funds; cash value in life insurance policies; valuable collections for investment purposes; rights in trusts or estates; shares of stock in publicly 
held corporations; mutual funds; investment trusts; stocks in IRAs; value of all vehicles, and value of all (partially or fully) owned farms and businesses. The value of all those assets is net of anything owed on them, such as the value of mortgages and due payments of car loans. Other debts that have been subtracted include: mortgages on other owned real estate, credit card charges, student loans, medical or legal bills and loans from relatives.

\section{Non-capital current income}

We calculate non-capital income as labor income plus transfers of the head, spouse, and all other members of the household. Labor income includes wages and salaries, overtime compensation, bonuses, commissions and tips, and income from the practice of a profession or trade, as well as the labor share of income from farm income and business income. Total transfers include: (a) ADC/AFDC, Supplemental Security Income and other welfare transfers; (b) Social Security transfers; (c) other retirement income, pensions and annuities; (d) unemployment compensation; (e) workmen's compensation; (f) child support transfers; (g) transfers from relatives and friends; and (i) food stamps, which are not included in any of the transfers above. All dollar values were deflated to 1997 dollars, using the CPI.

\section{Permanent income}

We consider two alternative definitions of permanent income. The first one is simply the time average of current income. For example, for a given household in the 1981-1987 panel, permanent income is average income over that period. We have also considered the time average of expenditures on food (the sum of food at home, food away 
from home and annual value of food stamps) over the same period as an alternative proxy for permanent income.

\section{Business owner}

A household is classified as business owner if answering 'yes' to the following question in the wealth supplement of the PSID: 'Do you (or anyone in your family living there) own part or all of a farm or business?' Our alternative definition of business owners is household head is self-employed. The exact wording of that question is 'Do you (head) work for someone else, yourself, or what?' The possible answers to this question are: (1) someone else; (2) both someone else and self; and (3) self only. A household is considered self-employed if the answer is either (2) or (3).

\section{SURVEY OF CONSUMER FINANCES (SCF)}

\section{B.1 Sample selection}

We use data from the 1995 SCF. To construct our final sample, we use as much as possible the same restrictions used to construct the PSID sample. To summarize the main restrictions, we drop households whose head is younger than 26 or older than 50 . We also drop households where the head of the household is not working and where the marital status of the head changed at any time during the last 5 years. When using log wealth, we exclude those observations with zero or negative wealth and zero desired precautionary savings.

\section{B.2. Definitions}

Net worth 
Net worth is defined as the sum of net savings and checking deposits, savings bonds, stocks net of margin loans, bonds, mutual funds, IRAs, net value of other retirement accounts, equity interests in annuities and trusts, housing equity, other real estate equity, business equity, net value of vehicles, net cash value of life insurance and the net values of miscellaneous assets minus all remaining debts.

\section{Permanent income}

Permanent income is taken to be a measure of "normal" income reported by SCF respondents. This question follows a sequence of questions on actual income. Each respondent was asked whether the total of all components of their income for the preceding year was unusually high or low compared to normal. In this case, the respondent was asked for the figure that would be more usual.

\section{Business owner}

A household is classified as being a business owner when reporting owning one or more businesses in which the household has either an active management role or a more passive investment role.

\section{B.3. Imputation of missing data}

Like most other surveys, the SCF deals with missing data through imputation, but it differs from most in imputing multiple values for each missing variable. Multiple imputations allow both statistically more efficient estimation of models with missing information and an estimate of the variance costs of the missing data. In the SCF, the nonmissing data and the imputations are provided as five replicates (or "implicates") for each observation (see Kennickell (1998) and Kennickell and Woodburn (1999)). For each of the five sets of replicates, we use a bootstrap procedure to estimate the standard 
errors attributable to the fact that the variances measures are estimated using the PSID data. We then combine the estimates of the coefficient estimates and standard errors for each replica (see Tables 7 and 8). Programs are available from the authors upon requests. 


\section{Table A1: Summary Statistics of PSID Sample: Full Sample, Business Owner Sample and Non-Business Owner Sample}

\begin{tabular}{lccc}
\hline \hline Variable & \multicolumn{3}{c}{ Mean } \\
\hline Average household non-capital income & 45,164 & 50,535 & 43,875 \\
Average household food expenditure & 13,160 & 13,873 & 12,988 \\
Age of head & 36.57 & 37.47 & 36.35 \\
Number of children & 1.38 & 1.41 & 1.37 \\
Percentage of married households & 85.35 & 93.73 & 83.34 \\
Percentage of white households & 92.91 & 97.11 & 91.90 \\
Percentage of female household heads & 8.82 & 1.69 & 10.53 \\
Mean wealth & 132,645 & 291,594 & 94,493 \\
Median wealth & 58,216 & 146,708 & 46,907 \\
$25^{\text {th }}$ percentile of wealth distribution & 22,995 & 71,285 & 18,041 \\
$75^{\text {th }}$ percentile of wealth distribution & 125,741 & 302,001 & 98,112 \\
& & & 1,729 \\
Number of observations & 2,144 & 415 & \\
\hline
\end{tabular}

Notes: All dollar amounts in 1997 dollars. Sample includes households in either the 1984 or the 1994 PSID between the ages of 26 and 50. See data appendix for additional sample restrictions. Average household non-capital income (food expenditure) is the average of household non-capital income (food expenditure) between 1981 and 1987 for households from the 1984 PSID and between 1991 and 1997 for households from the 1994 PSID. Non-capital income includes all income from wage and transfers received by the household. Average food expenditure is the monthly food on food at home and food away from home purchased by the household multiplied by 12 . 


\section{Table A2: Estimated Variances of Permanent and Transitory Income by Occupation Groups}

\begin{tabular}{|c|c|c|c|}
\hline Group & $\begin{array}{c}\text { Permanent } \\
\text { variance }\end{array}$ & $\begin{array}{c}\text { Transitory } \\
\text { variance }\end{array}$ & $\begin{array}{c}\text { Percent } \\
\text { of sample }\end{array}$ \\
\hline Total sample & $\begin{array}{c}0.0162 \\
(0.0023)\end{array}$ & $\begin{array}{c}0.0513 \\
(0.0040)\end{array}$ & 100 \\
\hline Professional and technical workers & $\begin{array}{c}0.0135 \\
(0.0042)\end{array}$ & $\begin{array}{c}0.0404 \\
(0.0069)\end{array}$ & 23.74 \\
\hline Managers (not self-employed) & $\begin{array}{c}0.0171 \\
(0.0048)\end{array}$ & $\begin{array}{c}0.0305 \\
(0.0083)\end{array}$ & 14.60 \\
\hline Managers (self-employed) & $\begin{array}{c}0.0272 \\
(0.0163)\end{array}$ & $\begin{array}{c}0.0866 \\
(0.0270)\end{array}$ & 5.27 \\
\hline Clerical and sales workers & $\begin{array}{c}0.0192 \\
(0.0075)\end{array}$ & $\begin{array}{c}0.0541 \\
(0.0128)\end{array}$ & 13.25 \\
\hline Craftsmen & $\begin{array}{c}0.0129 \\
(0.0043)\end{array}$ & $\begin{array}{c}0.0524 \\
(0.0079)\end{array}$ & 20.10 \\
\hline Operatives and laborers & $\begin{array}{c}0.0199 \\
(0.0055)\end{array}$ & $\begin{array}{c}0.0592 \\
(0.0094)\end{array}$ & 15.35 \\
\hline Farmers and farm laborers & $\begin{array}{c}0.0079 \\
(0.0209)\end{array}$ & $\begin{array}{l}0.1414 \\
(0.05)\end{array}$ & 2.01 \\
\hline Service workers & $\begin{array}{c}0.0126 \\
(0.0096)\end{array}$ & $\begin{array}{c}0.0547 \\
(0.0184)\end{array}$ & 5.69 \\
\hline
\end{tabular}

Note: Standard errors in parentheses. 
Table A3: Estimated Variances of Permanent and Transitory Income by Household Groups

\begin{tabular}{lccc}
\hline Group & $\begin{array}{c}\text { Permanent } \\
\text { variance }\end{array}$ & $\begin{array}{c}\text { Transitory } \\
\text { variance }\end{array}$ & $\begin{array}{c}\text { Percent } \\
\text { of sample }\end{array}$ \\
\hline Business owners & 0.0277 & 0.0763 & 19.36 \\
& $(0.0066)$ & $(0.0116)$ & \\
Non business owners & 0.0134 & 0.0453 & 80.64 \\
Self-employed & $(0.0023)$ & $(0.0041)$ & \\
& 0.0301 & 0.0923 & 16.14 \\
Non self-employed & $(0.008)$ & $(0.0142)$ & \\
& 0.0135 & 0.0435 & 83.86 \\
\hline
\end{tabular}

Note: Standard errors in parentheses. 
Table 1: Instrumental Variables Estimates of the Effect of Labor Income Risk on Log of Net Worth: Pooled Sample

\begin{tabular}{lc}
\hline \hline Variable & $\begin{array}{c}\text { Coefficient } \\
\text { (Standard Error) }\end{array}$ \\
\hline Variance of Permanent Income Shocks $\left(\alpha_{1}\right)$ & 15.91 \\
& $(2.98)$ \\
Variance of Transitory Income Shocks $\left(\alpha_{2}\right)$ & 7.52 \\
Percent of Net Worth Explained By Precautionary Savings & $(1.48)$ \\
& $47.5 \%$ \\
Sample Size & 2,144 \\
\hline
\end{tabular}

Notes: This table reports IV estimation of a regression of the log of net worth on the variance of permanent income shocks, transitory income shocks, and permanent income. The regression also includes controls for household demographics and past shocks to wealth. See text for full detail of additional variables included. Estimation was performed using PSID wealth data from 1984 and 1994. Sample was restricted to household between the age of 25 and 50. Permanent income is measured as average household non-capital income. The two variance measures as well as permanent income were instrumented using occupation dummies, industry dummies, interactions between occupation dummies with age and age squared, union status of household head, the county unemployment rate, and the variance of county unemployment rate. Sample pools together business owners and non-business owners. We compute the percent of net worth explained by precautionary savings by predicting net worth using the regression equation for each household. We then predict net worth using the regression equation for each household and setting permanent and transitory variances to zero. We compute the percent of net worth explained by precautionary saving by comparing these two predicted values. See text for full details. 


\section{Table 2: Estimates of the Effect of Labor Income Risk on Log of Net Worth: Pooled Sample, Alternate Specifications}

\begin{tabular}{lcccc}
\hline \hline Variable & I & II & III & IV \\
\hline Variance of Permanent Income Shocks $\left(\alpha_{1}\right)$ & 16.78 & & & 25.26 \\
& $(8.97)$ & & & $(5.73)$ \\
Variance of Transitory Income Shocks $\left(\alpha_{2}\right)$ & 0.05 & & & 13.01 \\
& $(3.33)$ & & & $(2.69)$ \\
Variance of Income & & 9.91 & 3.18 & \\
& & $(1.46)$ & $(1.89)$ & \\
Percent of Total Net Worth Explained by & $24 \%$ & $49 \%$ & $19 \%$ & $57 \%$ \\
Precautionary Savings & & & & \\
Sample Size & 2,144 & 2,144 & 2,144 & 2,198 \\
\end{tabular}

Notes: Specification I is the same as the regression presented in Table 1 except that the instrument set excludes occupation and industry dummies and add dummies for whether the wife works, whether there are other earners in the household and whether the worker is hourly paid. Specification II is the same as the regression presented in Table 1 except that the variance of permanent income shocks and the variance of transitory income shocks are replaced by the variance of total income. Specification III is the same as specification II except that the instrument set is the same as specification I. Specification IV is the same as regression presented in Table 1 except that the dependent variable is the ratio of net worth to average household non-capital income. The top and bottom $2 \%$ of the net worth to income ratio was excluded from the sample. Sample pools together business owners and non-business owners. See notes to Table 1 for a full description of the specification, the sample, and how we computed the percent of total net worth explained by precautionary savings. 


\section{Table 3: Instrument Variables Estimates of Labor Income Risk on Log of Net Worth: Non-Business Owners Only Sample}

\begin{tabular}{lc}
\hline \hline Variable & Non business owner Sample \\
\hline Variance of Permanent Income Shocks $\left(\alpha_{1}\right)$ & -0.63 \\
& $(3.65)$ \\
Variance of Transitory Income Shocks $\left(\alpha_{2}\right)$ & -0.70 \\
& $(1.58)$ \\
Percent of Total Net Worth Explained By & $-4.1 \%$ \\
Precautionary Savings & Log of Total Net Worth \\
Dependent Variable & Average Non-Capital Income \\
Measure of Permanent Income & 1,729 \\
Sample Size & \\
\hline
\end{tabular}

Notes: Estimations in this table is the same as the estimation reported in Table 1 except that the sample is restricted to non-business owners only. See notes to Table 1 for a full description of the specification and how we compute the percent of total net worth explained by precautionary savings. 
Table 4: Instrument Variables Estimates of the Effect of Labor Income Risk on Log of Wealth: Business Owners Only Samples

\begin{tabular}{|c|c|c|c|}
\hline Variable & I. & II. & III. \\
\hline Variance of Permanent Income Shocks $\left(\alpha_{1}\right)$ & $\begin{array}{c}6.79 \\
(3.05)\end{array}$ & $\begin{array}{c}3.38 \\
(2.82)\end{array}$ & $\begin{array}{c}2.85 \\
(2.62)\end{array}$ \\
\hline Variance of Transitory Income Shocks $\left(\alpha_{2}\right)$ & $\begin{array}{c}2.82 \\
(1.75)\end{array}$ & $\begin{array}{c}1.00 \\
(1.64)\end{array}$ & $\begin{array}{c}0.07 \\
(1.53)\end{array}$ \\
\hline $\begin{array}{l}\text { Percent of Total Net Worth Explained By } \\
\text { Precautionary Savings }\end{array}$ & $33.2 \%$ & $15.9 \%$ & $8.7 \%$ \\
\hline Dependent Variable & $\begin{array}{l}\text { Log of Total } \\
\text { Net Worth }\end{array}$ & $\begin{array}{c}\text { Log of Net } \\
\text { Worth Less } \\
\text { Business } \\
\text { Equity }\end{array}$ & $\begin{array}{c}\text { Log of Net } \\
\text { Worth Less } \\
\text { Business } \\
\text { Equity }\end{array}$ \\
\hline Measure of Permanent Income & $\begin{array}{c}\text { Average Non- } \\
\text { Capital } \\
\text { Income }\end{array}$ & $\begin{array}{c}\text { Average Non- } \\
\text { Capital } \\
\text { Income }\end{array}$ & $\begin{array}{c}\text { Average } \\
\text { Food } \\
\text { Expenditure }\end{array}$ \\
\hline Sample Size & 415 & 407 & 392 \\
\hline
\end{tabular}

Notes: Estimations in column I of this table is exactly the same as the estimation reported in Table 1 except that the sample is restricted to business owners only. See notes to Table 1 for a full description of the specification and how we compute the percent of total net worth explained by precautionary savings. Column II differs from column I in that the dependent variable is the $\log$ of non-business wealth. Column III differs from column II in that our measure of permanent income is average food expenditure rather than average non-capital income. 
Table 5: Estimates of the Effect of Labor Income Risk on Log of Non-Business Wealth: Pooled Sample, Accounting for Heterogeneity between Business Owners and Non-Business Owners

\begin{tabular}{lc}
\hline \hline Variable & $\begin{array}{c}\text { Coefficient } \\
\text { (Standard Error) }\end{array}$ \\
\hline Variance of Permanent Income Shocks $\left(\alpha_{1}\right)$ & 3.95 \\
& $(2.53)$ \\
Variance of Transitory Income Shocks $\left(\alpha_{2}\right)$ & 0.63 \\
Percent of Net Worth Explained By Precautionary Savings & $(1.23)$ \\
& $9.4 \%$ \\
Sample Size & 2,077 \\
\hline
\end{tabular}

Notes: Estimation and sample are the same as that used in Table 1 except that the dependent variable in this table is the $\log$ of non-business wealth (rather the log of total wealth ) and the measure of permanent income is average household food consumption (rather than average non-capital household income). See notes to Table 1 for a full description of the specification, the sample, and how we compute the percent of total net worth explained by precautionary savings. 
Table 6: Instrument Variables Estimates of the Effect of Labor Income Risk on Log of Wealth: Splitting Sample by Self-Employment Status

\begin{tabular}{lcc}
\hline Variable & I. & II. \\
\hline Variance of Permanent Income Shocks $\left(\alpha_{1}\right)$ & 1.48 & 1.47 \\
& $(4.02)$ & $(2.48)$ \\
Variance of Transitory Income Shocks $\left(\alpha_{2}\right)$ & -0.11 & 0.47 \\
& $(1.61)$ & $(1.25)$ \\
Percent of Total Net Worth Explained By & $1.5 \%$ & $8.4 \%$ \\
Precautionary Savings & & \\
& Log of Total Net & Log of Total Net \\
Dependent Variable & Worth & Worth \\
& Average Non-Capital & Average Non-Capital \\
Measure of Permanent Income & Income & Income \\
Sample Size & 1,798 & 346 \\
\end{tabular}

Notes: Estimations in column I of this table is exactly the same as the estimation reported in Table 1 except that the sample is split by self-employment status. See notes to Table 1 for a full description of the specification and how we compute the percent of total net worth explained by precautionary savings. Both regressions in this table use the log of total net worth as the dependent variable and use average non-capital income as the measure of permanent income. 
Table 7: Regression of Desired Precautionary Savings in the SCF on Labor Income Risk from the PSID

\begin{tabular}{|c|c|c|c|}
\hline Variable & $\begin{array}{c}\text { I. } \\
\\
\text { Full } \\
\text { Sample } \\
\end{array}$ & $\begin{array}{c}\text { II. } \\
\text { Non-business } \\
\text { owner } \\
\text { Sample } \\
\end{array}$ & $\begin{array}{c}\text { III. } \\
\text { Business } \\
\text { owners only } \\
\end{array}$ \\
\hline Variance of Permanent Income Shocks $\left(\alpha_{1}\right)$ & $\begin{array}{c}3.05 \\
(1.52)\end{array}$ & $\begin{array}{c}1.62 \\
(1.68)\end{array}$ & $\begin{array}{c}1.17 \\
(2.56)\end{array}$ \\
\hline Variance of Transitory Income Shocks $\left(\alpha_{2}\right)$ & $\begin{array}{c}2.25 \\
(0.62)\end{array}$ & $\begin{array}{c}0.92 \\
(0.73)\end{array}$ & $\begin{array}{c}1.81 \\
(0.86)\end{array}$ \\
\hline Sample Size & 1,497 & 1,046 & 451 \\
\hline
\end{tabular}

Note: This table reports the regressions of log of desired precautionary savings in the 1995 SCF on the variance of permanent income shocks, the variance of transitory income shocks, and additional controls such as permanent income, age, age squared, marital status, race, gender, and number of children. Column I uses the full sample of SCF households. Column II restricts the sample to no-business owners only. Column III restricts the sample to only business owners. The sample is restricted to all heads between the age of 25 and 50 and using the other restrictions in constructing the PSID sample described in the text. The variance measures were predicted using PSID data and fitting estimates back to the SCF using demographics (age, age squared, marital status, gender, race, sex and number of children), industry dummies, education and occupation dummies and these dummies interacted with age and age squared. Standard errors have been corrected to account for the fact that the variance measures are generated regressors from the PSID. 


\section{Table 8: Regression of Log Net Worth in SCF on Labor Income Risk from the PSID}

\begin{tabular}{|c|c|c|c|}
\hline Variable & $\begin{array}{c}\text { I. } \\
\text { Full Sample } \\
\end{array}$ & $\begin{array}{c}\text { II. } \\
\text { Non-business } \\
\text { owners }\end{array}$ & $\begin{array}{c}\text { III. } \\
\text { Business } \\
\text { owners only }\end{array}$ \\
\hline Variance of Permanent Income Shocks $\left(\alpha_{1}\right)$ & $\begin{array}{c}2.31 \\
(2.02)\end{array}$ & $\begin{array}{l}-3.40 \\
(2.13)\end{array}$ & $\begin{array}{c}2.95 \\
(3.34)\end{array}$ \\
\hline Variance of Transitory Income Shocks $\left(\alpha_{2}\right)$ & $\begin{array}{c}3.78 \\
(0.97)\end{array}$ & $\begin{array}{l}-1.43 \\
(0.98)\end{array}$ & $\begin{array}{c}5.14 \\
(1.39)\end{array}$ \\
\hline Dependent Variable & $\begin{array}{l}\text { Log of Total } \\
\text { Net Worth }\end{array}$ & $\begin{array}{l}\text { Log of Total } \\
\text { Net Worth }\end{array}$ & $\begin{array}{l}\text { Log of Total } \\
\text { Net Worth }\end{array}$ \\
\hline Measure of Permanent Income & $\begin{array}{l}\text { Normal } \\
\text { Income }\end{array}$ & $\begin{array}{l}\text { Normal } \\
\text { Income }\end{array}$ & $\begin{array}{l}\text { Normal } \\
\text { Income }\end{array}$ \\
\hline Sample Size & 1,497 & 1,046 & 451 \\
\hline
\end{tabular}

Notes: This table reports the regressions of log of net worth in the 1995 SCF on the variance of permanent income shocks, the variance of transitory income shocks, and additional controls such as permanent income, age, age squared, marital status, race, gender, and number of children. See Table 7 for a full description of the empirical specification. 


\section{Table 9: Level of Desired Precautionary Savings and Ratio of Desired Precautionary Savings to Total Wealth in the SCF}

\begin{tabular}{lcc}
\hline \hline \multicolumn{3}{c}{ Panel A: Level of Precautionary Savings } \\
\hline Sample & Mean & Median \\
\hline Business owners & $\$ 18,300$ & $\$ 7,100$ \\
Non-business owners & $\$ 10.400$ & $\$ 5,000$ \\
\hline \multicolumn{2}{c}{ Panel B: } & Ratio of Precautionary Savings to Total Wealth \\
\hline \multicolumn{2}{c}{$4 \%$} \\
Business owners & $4 \%$ & $5 \%$ \\
Non-business owners & $10 \%$ & $12 \%$ \\
\hline
\end{tabular}

Notes: Panel A reports the response to a survey question designed to measure how much savings a household desires to have due to uncertainty surrounding future income and consumption needs. See the text for the exact wording of the question. Panel B shows the ratio of desired precautionary savings to total net worth for the same sample of households. Data are from the 1995 Survey of Consumer Finances. The sample is restricted to households with heads aged between 25 and 50 and other restricted listed in the text. Sample size equals 1,497. 